This is the post print version of the article, which has been published in Journal of Business Strategy. 2018, 39 (4), 11-18.https://doi.org/10.1108/JBS-05-2017-0069.

Lahtinen Sonja, Kuusela Hannu, Yrjölä Mika

a This document has been downloaded from TamPub.uta.fi

\title{
The Company in Society: When Corporate Responsibility Transforms Strategy
}

\begin{abstract}
(250/ 250):
Purpose This study identifies and analyzes the different roles corporate social responsibility (CSR) can play in corporate strategy. By acknowledging that one of the biggest challenges for companies in committing to sustainability is the strategy work, the authors outline specific strategic initiatives to achieve these roles and the strategic outcomes that will follow such initiatives.

Design/methodology/approach Four illustrative case examples show how companies are recasting the role of CSR. The new CSR roles are characterized through two strategic dimensions: (1) an inside-out (firm-oriented) vs. outside-in (market-oriented) orientation, and (2) an emphasis on leveraging vs. an emphasis on prospecting activities.
\end{abstract}

Findings The findings show that to realize the opportunities of CSR for business, the environment, and society at large, the role of CSR in the boardroom must be reconfigured. By recasting its role, CSR can become a driver for the strategy process and a transformative force generating strategic changes.

Practical implications This paper aims to encourage top executives to take a proactive stance toward responsibility, recognize the new roles and potential impact that CSR can have in corporate strategy, and assist strategic decision-making regarding CSR.

Originality/value The paper aims to move beyond integrating sustainability into existing strategies and business models by demonstrating how sustainability can also inspire strategic changes a priori when the role of CSR is recast in companies. By viewing CSR as a driver of corporate strategy and strategic initiatives, the authors suggest that besides helping the environment, the community, and society, CSR can take care of corporate strategy. 


\section{Introduction}

Top executives' decision-making is strategic in nature: it includes considerations of the company's long-term viability and the ability to answer multifaceted challenges in the global environment. One of the domains increasingly attracting the attention of top executives is the strategic decision-making concerning corporate social responsibility (CSR). While most top executives today are recognizing the environmental, economic, and social challenges related to their business and making necessary changes to their business operations, a clear understanding of the role of CSR in corporate strategy remains a challenge for many. Prior research has widened our understanding of the strategic nature of CSR by focusing on integrating sustainability into existing strategies and business models. In this paper, we demonstrate how sustainability can also inspire new strategic initiatives and drive strategic changes a priori when the role of CSR is recast in companies.

The purpose of this study is therefore to identify and analyze the different roles that CSR can take in corporate strategy. By acknowledging that one of the biggest challenges for companies in committing to sustainability is the strategy work (Bonn and Fisher, 2011), we outline specific strategic initiatives that companies can undertake, and propose well-defined roles for CSR that might help companies to understand the opportunities sustainability can offer. We also shed light on the strategic outcomes that companies might expect when they undertake these initiatives.

This paper addresses the call for a new approach to strategy regarding sustainability issues (McPhee, 2014). We argue that through role recasting, CSR can become a transformative force generating strategic changes, rather than only an "ingredient"—or a "retroactive addition" (Alberti et al., 2017) — that needs to be integrated into the existing corporate strategy. Thus, we encourage companies to take a proactive stance toward sustainability in their strategy, and we characterize the new CSR roles through two strategic dimensions: (1) an inside-out (firm-oriented) vs. outside-in (market-oriented) orientation, and (2) an emphasis on leveraging vs. an emphasis on prospecting activities. We use illustrative case examples to show how four different companies, each operating in challenging industries regarding responsibility, are recasting the role of CSR by approaching it as a strategic opportunity to make an impact on business, people, and the planet, also known as the triple bottom line (Elkington, 1997). 


\section{The evolving role of CSR}

Mirroring the changing landscape of business and the environment at large, the concept and usage of CSR is constantly evolving and taking new forms. Building on to the ideas of Carroll (1999), we propose that CSR consists of legal, economic, ethical, and operational dimensions, which are complementary — rather than contradictory—ways of viewing the concept. Thus, we argue that CSR, as a definitional construct, is multidimensional.

As stated by Matten and Moon (2008, 405), "at the core of CSR is the idea that it reflects the social imperatives and the social consequences of business success.” By following the recent strategic turn in CSR literature, we propose that CSR also reflects the strategic opportunities for business success, amplifying the strategic imperative for responsible business decisions. As the evidence presented in previous studies shows (e.g., Bonn and Fisher, 2011; McPhee, 2014; Palmer and Flanagan, 2016), approaching CSR as a strategic issue is pivotal for companies today. However, to realize the multifaceted opportunities of CSR for business, its role in corporate strategy needs clarification. As top executives are responsible for shaping sustainable corporate strategies, we analyze their strategic decision-making to uncover how the role of CSR can be reconfigured.

\section{Dimensions of strategic decision-making}

In analyzing the different roles that CSR can take in corporate strategy, it is necessary to distinguish two strategic dimensions: (1) an inside-out (firm-oriented) vs. outside-in (market-oriented) orientation, and (2) an emphasis on leveraging vs. an emphasis on prospecting activities. First, top executives must balance the two orientations in their strategic decision-making: inside-out and outside-in (Saeed et al., 2015). An inside-out orientation involves making the organization's current strengths, products, and capabilities the starting point for the strategy. This type of decision-making starts with identifying the unique assets and capabilities of the organization and then searching for potential markets and strategies to leverage these unique resources. The focus is on choosing the core businesses or product categories to operate in, utilizing assets, improving productivity, and maximizing market share. Inside-out decisions include, for example, cost control, human resource management, and technology development.

An outside-in decision-making orientation takes the market as the starting point for the strategy. The focus is on interpreting market signals, such as competitor behavior, consumer trends, and customer 
processes (Saeed et al., 2015). These insights are then used to anticipate, influence, and meet marketplace changes by developing new capabilities and offerings (Day and Moorman, 2010). According to this view, companies' interactions with market actors and stakeholders create valuable assets, including relationships, market insights, and goodwill (Day and Moorman, 2010; Saeed et al., 2015).

Second, top executive decision-making can aim to either leverage current resources and capabilities or create new ones (March, 1991). In this study, the former type of thinking, concerned with emphasizing current (and more certain) resources, capabilities, and revenues, is labelled "leveraging”. It can involve elements such as efficiency, refinement, and execution (March, 1991). Leveraging can be targeted at internal aspects, such as improving production processes, or external ones, such as utilizing the brand to generate more revenue. The latter type of thinking, which we label "prospecting," is more explorative in nature and concerned with future resources, capabilities, and revenue streams. Hence, prospecting is more risk-seeking in nature. It can include aspects such as discovery, innovation, and experimentation (March, 1991). Prospecting can involve internal possibilities, such as new technology development, or external ones, such as seizing new market opportunities.

We argue that top executives must balance these two dimensions in their strategic decision-making regarding the role of CSR. For instance, due to an overemphasis on internal processes, the inside-out orientation might distance the organization from its market and stakeholders. On the other hand, the outside-in orientation might be inefficient or cause the organization to lose its distinctive resources and capabilities if too much effort is put into chasing market trends or pleasing all outside stakeholders (Day and Moorman, 2010). Similarly, prospecting for new opportunities will take resources away from improving existing competencies (March, 1991).

\section{Empirical study}

\subsection{Methodology}

The qualitative case study method allowed us to investigate the contemporary and complex issue of CSR within its real-life context, offering a practical and accessible format for the study (Yin, 2014). The four case studies presented below explicate the ways companies are recasting the role of CSR in their strategy, the strategic initiatives through which these roles are achieved, and the strategic outcomes that this role recasting can provide to proactive companies. In studying these cases, we used two different kinds of data. The primary data were generated through semi-structured interviews 
(varying from 50 to 80 minutes) with senior sustainability and CSR managers who are involved in the strategic decision-making of the executive teams. The secondary data consist of annual reports, sustainability reports, and other public materials from these companies. An interpretive approach was used to analyze the central qualities of the data. To ensure anonymity, companies are identified by the letters A-D.

\subsection{Illustrative case examples}

Given the complex, extensive, and long-term nature of strategic decision-making, we provide a roadmap, which aims to assist senior managers and top executives in rethinking the role of CSR in corporate strategy (Figure 1). The roadmap captures the dimensions identified in our previous theoretical discussion. The illustrative case examples represent companies in both the B2B and B2C sectors, operating in the alcoholic beverage, food manufacturing, paper, and forest industries, each experiencing high pressure in terms of CSR. To engage stakeholders, enhance business performance, stimulate innovation, and transform the market based on sustainability, these companies are moving from merely integrating responsibility in their existing business models to transforming the way they do_-and value_-business.

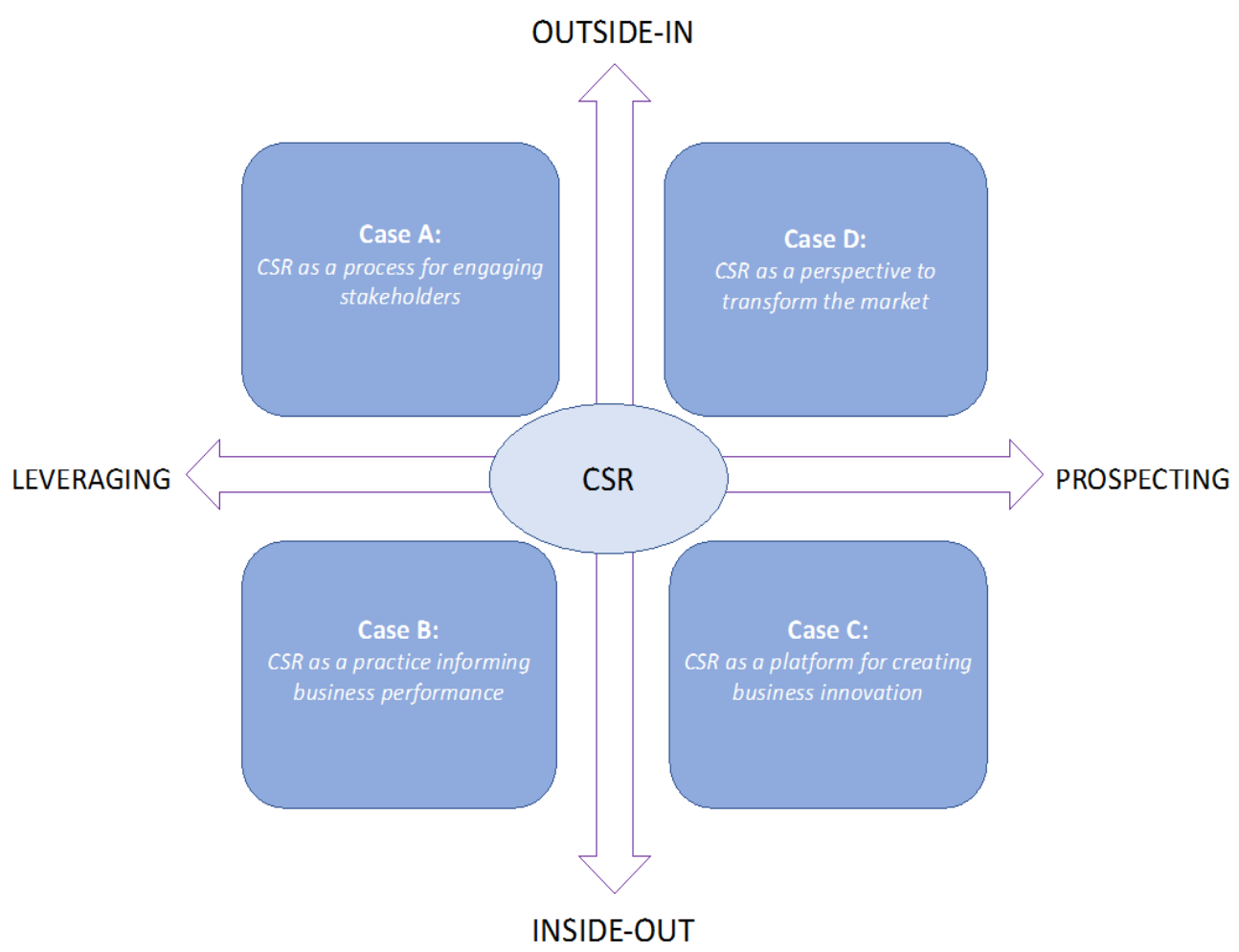

Figure 1. Roadmap to reconfiguring the role of CSR. 


\section{Case Company A}

One of the greatest challenges in CSR strategy comes from adjusting the operations of the company to the expectations of a broad network of stakeholders. Company A, a national alcoholic beverage retailer, operates with multiple stakeholders and has been struggling to balance the conflicting expectations toward the company and its special role in society. The company has a state-granted monopoly to sell alcoholic beverages containing more than 5.5 per cent alcohol per volume, and in 2015 its retail sales amounted to 1.2 billion euros. Naturally, selling products with harmful effects is the primary challenge for the responsible management of the company, but while the requirement for the company's responsibility comes from legislation, it has been looking for other ways to go beyond normative compliances to emphasize its role as a responsible player in the community.

Company A has implemented several strategic initiatives to work on environmental, economic, and social issues that are important and meaningful to its multiple stakeholders. To enable idea-sharing among all its stakeholders, the company invited all twelve key stakeholder groups-including customers, suppliers, owners, employees, authorities, and the media-to take part in the process of planning, developing, and implementing the responsible actions of the company. With over 1,300 ideas originating from its key stakeholders, the “Online Think Tank” has become an exceptional source of ideas and opportunities. By investing in issues that are recognized as important by stakeholders, Company A is embracing the concept of “stakeholder democracy” (O’Dwyer, 2005).

In terms of role recasting, Company A approaches CSR as a process for engaging stakeholders. As shown in Figure 1, by making the market the starting point for the CSR strategy and seeing the collaboration with stakeholders as an opportunity to create valuable assets, Company A is following the outside-in orientation and leveraging existing resources, in the form of stakeholder relationships, in its strategic decision-making. Strategic outcomes, such as greater stability within different stakeholder relationships, a minimized risk of conflict between divergent objectives, and an increased flow of market insight, create value for both the company and its stakeholders, as stakeholders can now influence rather than be influenced by Company A’s responsible actions.

\section{Case Company $B$}

Goal-setting and measurement are prominent but difficult components of any CSR strategy (Palmer and Flanagan, 2016). The case of Company B, a leading globally operating paperboard company, shows how the company has been struggling to measure, manage, and promote the impacts its sustainability operations have on the overall business performance, even though it is recognized as one of the world's leading companies in sustainable forestry and responsible business. As a listed 
company with sales of 2.0 billion euros in 2015 and operating in an industrial sector with a huge influence on global forests and sustainability, the company decided to tackle the challenge of measurement to turn the intangible benefits into measurable value for business.

Company B has undertaken several strategic initiatives to reveal the competitive advantage and improved business performance resulting from its sustainable actions, impacts, and achievements. One of these initiatives is conducting a materiality assessment through which the company has recognized the relative importance of its environmental and social activities, the ten goals that have been developed based on this assessment, and the set of key metrics that have been defined to assess its effectiveness in achieving these goals. The company has also integrated sustainability goals into the overall business performance objectives. By enlisting the senior management group in goal-setting and training all employees to understand how these goals can be achieved in their jobs, the company has ensured rigorous engagement with sustainability at all levels and has illustrated explicitly the advantages of CSR activities for its business.

Company $\mathrm{B}$ is recasting the role of CSR by viewing CSR as a practice informing business performance. Figure 1 illustrates how the company is leveraging its current resources in its strategic decision-making and emphasizing the inside-out orientation by refining the existing sustainability program in terms of goal-setting and measurement. The new role of CSR provides strategic outcomes, such as decreased costs of raw material, water, and energy use; an increased capability to differentiate the company from other, less responsible pulp and paper operators; and enhanced access to new markets and customer segments. The integrated goals and the established metrics are used for motivating, evaluating, and diagnosing sustainability's influence on overall business performance (Palmer and Flanagan, 2016) while establishing the business legitimacy.

\section{Case Company C}

One drawback of current CSR strategies stems from companies focusing on incremental adjustments, instead of innovating new business opportunities based on sustainability. The case of Company C, a leading forestry company, shows how taking an innovative approach to responsibility can create value for the business, stakeholders, and society. With sales of 9.8 billion euros in 2015, the company has moved from focusing on gradual improvements in sustainability performance to finding innovative and radical solutions to global problems. To address systemic innovations, it has created a completely new business concept based on sustainable solutions, bringing the company at the forefront of developing a modern forestry industry. 
To envision and implement new sustainability-driven business innovations, Company C has undertaken several strategic initiatives at the production, product, and organizational levels. At the production level, the company has invested in cleaner technology and resource efficiency, meaning that as natural resources are used in a judicious manner, energy-, production-, and cost efficiency has improved. By allocating resources to developing sustainable products, the company has launched unique products and solutions aligned with their “eco-design” approach, which guarantees that when products reach the end of their life cycle, they can be used for something new. At the organizational level, the radicalness of the sustainable innovations has enabled the company to innovate new business models by recognizing that its activities are linked to the larger ecosystem of which it is part (Boons et al., 2013).

By taking a systemic approach to responsibility, Company $\mathrm{C}$ is recasting the role of CSR by seeing CSR as a platform for creating new business innovations. As illustrated in Figure 1, in its strategic decision-making, the company is prospecting for new, future resources and capabilities in the form of innovation, and taking an inside-out orientation by improving its production processes, developing new products, and crafting new business models. Sustainable innovation is defined as "a process where sustainability considerations (environmental, social, and financial) are integrated into company systems from idea generation through to research and development and commercialization. This applies to products, services and technologies, as well as to new business and organizational models (Boons et al., 2013, 3). The strategic outcomes of engaging in sustainable innovations represent the improved utilization of resources and raw materials, an enhanced ability to attract innovative and motivated employees, and increased opportunities to develop new businesses and harness the potential of sustainability as a competitive advantage.

\section{Case Company D}

In today's CSR strategies, companies need to exceed national product safety requirements to meet their responsibility to consumers' health and wellbeing. Company D, a leading food industry group with net sales of 330 million euros in 2015, has been greatly influencing consumers' wellbeing through its convenience food products for decades. Indeed, many factors related to convenience food, such as poor nutritional content, heavily processed products, and the use of harmful additives, might damage consumer health. Recognizing its role in contributing to the long-term health of the nation, the company has developed its CSR program to better address issues related to nutrition and improve balanced eating habits. 
Company D has implemented a number of strategic initiatives to support customers' present and future wellbeing. After recognizing that some of its food products did not meet the national objectives, the company drafted new nutritional guidelines for its products and launched a new, nutritionally balanced meals brand. The company has also improved consumers' access to nutritional information, which is regarded as one of the most promising instruments in promoting healthy choices. It has also fortified its nutritional expertise by hiring a nutrition specialist and intensified its collaboration with the National Nutrition Council. The company recognized that as a food manufacturer, it can promote not only healthier products, but also healthier eating habits.

By expanding its responsibility to transform consumer behavior toward healthier eating, Company D approaches CSR as a perspective to transform the market. In its strategic decision-making, it is prospecting new resources by seizing the market opportunity of consumers' health consciousness and following the outside-in orientation by influencing the ways consumers choose and eat food (Figure 1). The new role of CSR embraces transformative action, which "aims to improve life in relation to the myriad conditions, demands and potentialities of a fundamental problem” (Mick, 2006, 2). Strategic outcomes-such as greater influence on consumers' wellbeing, increased revenue stream from new products in the product portfolio, and reduced risk of a negative image and reputationshow the potential of transformative actions to create a competitive advantage in the marketplace and go beyond individual wellbeing toward a collective, positive impact (Saarijärvi et al., 2015). 
Table 1 . The roles, strategic initiatives, and strategic outcomes of role recasting.

\begin{tabular}{|c|c|c|c|}
\hline Case/role & Strategic initiatives & Strategic outcomes & Illustrative quote \\
\hline $\begin{array}{l}\text { Case A: } \\
\text { CSR as a process for } \\
\text { engaging stakeholders }\end{array}$ & $\begin{array}{l}\text { - Enabling idea-sharing } \\
\text { among all stakeholders in } \\
\text { an online think tank } \\
\text { - Investing in sustainability } \\
\text { issues recognized as } \\
\text { meaningful by multiple } \\
\text { stakeholders } \\
\text { - Embracing stakeholder } \\
\text { democracy through two- } \\
\text { way information flow }\end{array}$ & $\begin{array}{l}\text { - Greater stability in } \\
\text { different stakeholder } \\
\text { relationships } \\
\text { - Minimized risk of } \\
\text { conflict between divergent } \\
\text { objectives } \\
\text { - Increased market insight }\end{array}$ & $\begin{array}{l}\text { "All our stakeholders } \\
\text { have high expectations } \\
\text { regarding our responsible } \\
\text { actions. We see it as a } \\
\text { prerequisite to our } \\
\text { existence that we can } \\
\text { keep up with and fulfill } \\
\text { those expectations, } \\
\text { which are constantly } \\
\text { growing and changing." }\end{array}$ \\
\hline $\begin{array}{l}\text { Case B: } \\
\text { CSR as a practice } \\
\text { informing business } \\
\text { performance }\end{array}$ & $\begin{array}{l}\text { - Creating a set of goals } \\
\text { and metrics based on } \\
\text { materiality assessment } \\
\text { - Integrating sustainability } \\
\text { goals into business } \\
\text { performance objectives } \\
\text { - Ensuring senior } \\
\text { management engage in } \\
\text { sustainability goal-setting, } \\
\text { and training employees }\end{array}$ & $\begin{array}{l}\text { - Decreased costs of raw } \\
\text { material, water, and energy } \\
\text { use } \\
\text { - Enhanced access to new } \\
\text { markets and customers } \\
\text { - Improved marketing } \\
\text { position }\end{array}$ & $\begin{array}{l}\text { "It is necessary for us } \\
\text { that investing in } \\
\text { sustainability also builds } \\
\text { our competitive } \\
\text { advantage and increases } \\
\text { profitability. However, } \\
\text { the benefits of CSR } \\
\text { actions to profitability } \\
\text { are as difficult to } \\
\text { measure as measuring } \\
\text { marketing ROI." }\end{array}$ \\
\hline $\begin{array}{l}\text { Case C: } \\
\text { CSR as a platform for } \\
\text { creating new business } \\
\text { innovations }\end{array}$ & $\begin{array}{l}\text { - Investing in cleaner } \\
\text { technology and resource } \\
\text { efficiency } \\
\text { - Allocating resources for } \\
\text { developing ecological and } \\
\text { renewable products } \\
\text { - Innovating business } \\
\text { models to hamess the } \\
\text { potential of sustainability }\end{array}$ & $\begin{array}{l}\text { - Improved utilization of } \\
\text { renewable resources and } \\
\text { raw materials } \\
\text { - Enhanced ability to } \\
\text { attract innovative and } \\
\text { motivated employees } \\
\text { - Increased opportunities } \\
\text { to develop new businesses }\end{array}$ & $\begin{array}{l}\text { "Our responsibility } \\
\text { program doesn't only } \\
\text { mean numbers and } \\
\text { figures about how much } \\
\text { we are reducing or } \\
\text { improving certain } \\
\text { indicators year-on-year- } \\
\text { For us, this entire } \\
\text { company is a } \\
\text { responsibility program." }\end{array}$ \\
\hline $\begin{array}{l}\text { Case D: } \\
\text { CSR as a perspective to } \\
\text { transform the market }\end{array}$ & $\begin{array}{l}\text { - Drafting new nutritional } \\
\text { guidelines for developing } \\
\text { healthier products } \\
\text { - Investing in recruiting an } \\
\text { nutritional specialist and } \\
\text { collaborating with the } \\
\text { National Nutrition Council } \\
\text { - Improving access to } \\
\text { product information }\end{array}$ & $\begin{array}{l}\text { - Greater influence on } \\
\text { consumers' wellbeing } \\
\text { - Increased revenue stream } \\
\text { from new products in } \\
\text { portfolio } \\
\text { - Reduced risk of negative } \\
\text { image and reputation }\end{array}$ & $\begin{array}{l}\text { "It is easier to recognize } \\
\text { the effects of responsible } \\
\text { actions retrospectively, } \\
\text { than to operate } \\
\text { prospectively, toward the } \\
\text { future. However, I feel } \\
\text { we are getting there, } \\
\text { taking greater } \\
\text { responsibility of our } \\
\text { customers" well-being." }\end{array}$ \\
\hline
\end{tabular}

\section{Discussion}


This paper addresses the call for a new approach to strategy regarding sustainability (McPhee, 2014). We have argued that the role of CSR in the boardroom needs to be reconfigured, and we have illustrated potential new roles for CSR through two strategic dimensions: (1) an inside-out (firmoriented) vs. outside-in (market-oriented) orientation, and (2) an emphasis on leveraging vs. an emphasis on prospecting activities. Four case examples illustrate how frontrunner companies are meeting this challenge. By reconfiguring the role of CSR, they are recognizing opportunities in measuring performance, innovating new business, engaging stakeholders, and transforming the market toward true sustainability. These companies are not only limited to such CSR fundamentals as people and society, product stewardship, supply chain management, or material use. They are further harnessing the transformative potential of CSR to drive strategic initiatives that result in impactful strategic outcomes (Table 1).

The key contribution for top executives aiming for this transformation lies in recognizing the plurality of roles that CSR can take in corporate strategy and the strategic initiatives to enact these roles. Reflecting on Figure 1, executives can critically assess the current role of CSR in their organization and evaluate the most relevant roles for their organizational context and aspirations. Building on this, we encourage executives to view CSR as a driver of corporate strategy and strategic initiatives. Given this new role, we suggest that CSR can assist executives in evaluating and defining the critical elements of their strategy statements, namely the objective, scope, and advantage of the business (Collis and Rukstad, 2008). Knowing what the business aims to achieve (objective), the means of getting there (advantage), and the domain where the company will operate (scope) are all-important for an effective strategy (Collis and Rukstad, 2008), and they can be crystallized by adopting CSR as a strategic tool.

We argue that CSR is, by nature, multifaceted and complex. This is evident in the multiple roles CSR can take in corporate strategy, but also in other organizational dimensions. CSR influences many domains of business, and thus it should not be thought to belong to just one organizational function (e.g., Public Relations) or hierarchical level. Furthermore, CSR involves both ways of doing and ways of thinking inside the organization. We have analyzed CSR from a strategic perspective and argue that when seen as a strategic tool, CSR can offer more than guidance to mission statements or ethical values. It can help executives carry out new strategic initiatives involving resource and energy efficiency, sourcing, and stakeholder engagement that create value in various ways. For instance, these initiatives may give the company a more transparent image and help build a favorable brand position in consumers' minds. 
Scholars and practitioners have long viewed CSR as a way of taking care of the environment, community, and society (Kudlak and Low, 2015) that is separate from strategy. We propose that CSR should be viewed next as taking care of corporate strategy. As Porter identified, tradeoffs are fundamental to strategy, but as Alberti et al. (2017) show, sustainability and profit goals can co-exist and turn the traditional trade-offs into new business strategies. More than co-existing, we suggest that by reconfiguring the role of CSR, sustainability and profit goals can cooperate in corporate strategy and lead companies to promising opportunities and a positive social impact.

\section{References}

Alberti, F.G. and Garrido, M.A.V. (2017),"Can profit and sustainability goals co-exist? New business models for hybrid firms", Journal of Business Strategy, Vol. 38 No. 1, pp. 3-13.

Bonn, I. and Fisher, J. (2011), "Sustainability: the missing ingredient in strategy", Journal of Business Strategy, Vol. 32 No. 1, pp. 5-14.

Boons, F. and Ludeke-Freund, F. (2013), "Business models for sustainable innovation: state of the art and steps towards a research agenda”, Journal of Cleaner Production, Vol. 45, pp. 9-19.

Carroll, A.B. (1999), “Corporate social responsibility: evolution of a definitional construct”, Business \& Society, Vol. 38 No. 3, pp. 268-295.

Collis, D.J. and Rukstad, M.G. (2008), "Can you say what your strategy is?", Harvard Business Review, Vol. 86 No. 4, pp. 82-90.

Day, G. and Moorman, C. (2010), Strategy From the Outside In: Profiting from Customer Value, McGraw Hill Professional, New York, NY.

Elkington, J. (1997), Cannibals with Forks: The Triple Bottom Line of the 21st Century Business, Capstone, Oxford.

Kudlak, R. and Low, K. (2015), "Special issues dedicated to CSR and corporate sustainability: a review and commentary’. Long Range Planning, Vol. 48 No. 3, pp. 215-227.

March, J.G. (1991), “Exploration and exploitation in organizational learning”, Organization Science, Vol. 2 No. 1, pp. 71-87.

Matten, D. and Moon, J. (2008), "’'Implicit" and "explicit" CSR: a conceptual framework for a comparative understanding", The Academy of Management Review, Vol. 33 No. 2, pp. 404-424.

McPhee, W. (2014), “A new sustainability model: engaging the entire firm”, Journal of Business Strategy, Vol. 35 No. 2, pp. 4-12. 
Mick, D.G. (2006), “Meaning and mattering through transformative consumer research", In Pechmann, C. and Price, L.L. (Eds.), Advances in consumer research, Vol. 33, pp. 1-4.

O’Dwyer, B. (2005), “Stakeholder democracy: challenges and contributions from social accounting”, Business Ethics, Vol. 14 No. 1, pp. 28-41.

Palmer, T. B. and Flanagan, D. J. (2016),"The sustainable company: looking at goals for people, planet and profits ", Journal of Business Strategy, Vol. 37 No. 6, pp. 28-38.

Saarijärvi, H., Kuusela, H., Kannan, P. K., Kulkarni, G. and Rintamäki, T. (2015), ”Unlocking the transformative potential of customer data in retailing”, The International Review of Retail, Distribution and Consumer Research, Vol. 26 No. 3, pp. 225-241.

Saeed, S., Yousafzai, S., Paladino, A. and De Luca, L.M. (2015), "Inside-out and outside-in orientations: a meta-analysis of orientation's effects on innovation and firm performance", Industrial Marketing Management, Vol. 47, pp. 121-133.

Yin, R. (2014), Case Study Research, Sage, Thousand Oaks, CA. 